\title{
Pemilihan Provider Sand Consolidation dengan Metode Analytical Hierarchy Process
}

\author{
Rony Arjuna $^{1}$, Joko Waluyo ${ }^{2}$, Nur Aini Masruroh ${ }^{3}$ \\ ${ }^{1}$ Magister Teknik Sistem, Fakultas Teknik, Universitas Gadjah Mada, \\ ${ }^{2}$ Departemen Teknik Mesin dan Teknik Industri, Fakultas Teknik, Universitas Gadjah Mada \\ Email: ronyarjuna@yahoo.com
}

Received: May 8, 2021; Accepted : May 28, 2021; Published : May 31, 2021

\begin{abstract}
One of the sand control methods commonly used by oil and gas companies for well maintenance work is sand consolidation (SCON). The process of selecting providers has been carried out by auction. To select the provider to be more transparent, measurable, and accountable, it is necessary to design a standardized decision-making system that is compatible with existing problems. This study aimed to determine what parameters are the basis for consideration in choosing a provider and designing a decision-making system. The method used in this research is Analytical Hierarchy Process (AHP). The results indicate that the parameters taken into consideration are compatibility (0.349), safety \& environment (0.229), quality (0.219), cost (0.127), and finally service (0.075). ST- $\alpha 2-H L$ with a weight of 0.282 is the chosen provider. AHP can be applied as an excellent method in the case of determining the best alternative for SCON providers. The comparison of the results between the decision-maker and the AHP method from the perspective of the best alternative only reaches $100 \%$.
\end{abstract}

Keywords: Sand problem, Sand Consolidation (SCON), Analytical Hierarchy Process

\section{ABSTRAK}

Salah satu metode sand control yang umum digunakan oleh perusahaan oil dan gas untuk pekerjaan perawatan sumur adalah sand consolidation (SCON). Selama ini, proses pemilihan provider pelaksana pekerjaan dilakukan secara lelang. Kemudian pimpinan departemen dan engineer akan memutuskan providernya. Agar proses pemilihan lebih transparan, terukur dan bisa dipertanggung jawabkan, maka diperlukan suatu sistem pengambilan keputusan yang standar dan kompatibel. Penelitian ini bertujuan untuk mengetahui parameter apa yang menjadi dasar pertimbangan dan merancang sistem pengambilan keputusannya. Metode yang digunakan dalam penelitian ini adalah Analytical Hierarchy Process (AHP). Hasil dari penelitian ini menunjukkan kriteria yang dijadikan sebagai pertimbangan adalah compatibility $(0,349)$, safety \& environment $(0,229)$, quality $(0,219)$, cost $(0,127)$, dan service $(0,075)$. Alternatif ST- $\alpha 2-$ HL dengan bobot 0,282 merupakan provider terpilih. AHP dapat diterapkan sebagai metode yang sangat baik dalam kasus penentuan best alternatif provider SCON. Perbandingan hasil antara decision maker dan metode AHP jika dilihat dari perspektif best alternatif saja mencapai $100 \%$.

Kata Kunci : Masalah kepasiran, Sand Consolidation (SCON), Analytical Hierarchy Process

\section{PENDAHULUAN}

Salah satu kegiatan operasional utama selain membuka sumur baru di perusahaan minyak dan gas bumi adalah pekerjaan perawatan sumur-sumur tua yang masih potensial untuk dikelola. Departemen well intervention adalah departemen yang bertanggung jawab terhadap pekerjaan tersebut. Dalam proses pengerjaannya, beberapa pekerjaan yang beruhubungan dengan perawatan tetap melibatkan pihak ketiga sebagai pelaksananya dan perusahaan hanya sebagai pengawas pekerjaan tersebut. Artinya tidak semua pekerjaan dilakukan secara mandiri oleh internal perusahaan.

Salah satu contoh pekerjaan departemen well intervention yang melibatkan pihak ketiga adalah pekerjaan penanggulangan masalah kepasiran. Permasalahan kepasiran adalah kondisi dimana ikut terproduksinya pasir menuju permukaan bersamaan dengan proses produksi fluida reservoir. Kepasiran ini bisa menyebabkan beberapa permasalahan jika dibiarkan dalam waktu yang lama diantaranya adalah wellbore sanding, erosion, sand fouling dan sand accumulation. Kemampuan untuk melakukan pengontrolan sand production (sand control) menjadi salah satu kunci efektivitas proses produksi pada sumur-sumur 
penghasil minyak dan gas bumi. Kegiatan sand control ini merupakan upaya pencegahan agar tidak terproduksinya pasir melebih batas ambang yang telah ditentukan. Beberapa metode sand control yang umum digunakan antara lain adalah gravel packing (internal/eksternal), expandable sand screens (ESS), stand alone screens (SAS), frac packs, dan SCON [1].

Dalam proses produksi minyak dan gas bumi sangat dibutuhkan metode sand control terutama untuk menangani reservoir yang memiliki karakteristik berpasir [2]. Permasalahan kepasiran ini pernah terjadi di PT X pada bulan Agustus tahun 2019, yang menyebabkan kerusakan peralatan yang cukup serius. Kegiatan operasional bahkan harus diberhentikan selama 12 hari di titik lokasi kejadian dan hal ini tentu saja menyebabkan kerugian dari sisi materi yang tidak sedikit bagi perusahaan. Oleh karena itu penanganan masalah kepasiran ini menjadi salah satu hal yang harus diperhatikan oleh perusahaan.

Metode sand control sebenarnya dapat diklasifikasikan dalam tiga kategori yaitu mekanik, kimia dan kombinasi keduanya [3]. Salah satu metode sand control yang saat ini digunakan pada sumur-sumur di PT X adalah chemical sand consolidation (SCON). Prinsip kerja Chemical SCON adalah dengan cara menginjeksi bahan kimia kedalam formasi biasanya berupa resin dengan tujuan untuk menyemen butiran pasir. Bahan kimia ini nantinya akan mengikat partikel batuan bersama sama untuk membuat susunan formasi yang stabil sehingga mencegah ikut terproduksinya pasir [3]. Sejak tahun 2009 sampai dengan 2020 sudah ada sekitar 3 provider dengan masing-masing chemical sand consolidation (SCON) treatment yang berbeda-beda yang telah bekerja sama dengan perusahaan. Selama ini, proses pemilihan provider pelaksana pekerjaan SCON dilakukan secara lelang oleh perusahaan, artinya masing-masing provider nantinya akan mengajukan proposal dengan paparan berupa hal teknis penanganan kepasiran beserta total biayanya. Selanjutnya pihak perusahaan akan melakukan proses seleksi untuk menentukan provider mana yang akan dipilih. Tidak ada aturan dan metode yang baku dalam proses seleksi provider, biasanya para pimpinan departemen dan engineer yang terlibat langsung akan melakukan diskusi bersama dan memutuskan akan memilih provider mana yang akan digunakan sebagai pihak ketiga untuk melaksanakan pekerjaan sand control dengan metode sand consolidation (SCON). Oleh karena itu, agar proses pemilihan provider lebih transparan, terukur dan bisa dipertanggungjawabkan maka diperlukan suatu sistem pengambilan keputusan yang standar dan kompatibel dengan permasalahan penentuan provider pelaksana sand consolidation (SCON).

Beberapa penelitian terdahulu terkait penyelesaian permasalahan sistem pengambilan keputusan telah banyak dilakukan, hal ini dapat dilihat pada sitasi di daftar pustaka. Salah satu metode penyelesaian permasalahan pengambilan keputusan yaitu menggunakan Analytical Hierarchy Process (AHP). Metode AHP sangat efektif untuk menyelesaikan permasalahan multi kriteria yang kompleks [4]. Struktur hierarki dari AHP dapat menggambarkan suatu permasalahan kompleks menjadi struktur multi level sehingga lebih mudah untuk dipahami dan diselesaikan nantinya [5]. Alasan pemilihan metode AHP karena merupakan salah satu metode yang relevan dengan kasus yang terjadi di PT X, dimana AHP ini nantinya akan digunakan sebagai alat bantu pengambil keputusan pemilihan provider SCON, disamping itu dengan menggunakan AHP dapat juga dilakukan perhitungan tingkat konsistensi terkait penentuan prioritas masing-masing kriteria, dimana kriteria yang dipilih bisa bersifat kuantitatif dan kualitatif.

Berikut ini penjelasan beberapa penelitian yang menggunakan AHP sebagai metode yang digunakan sebagai alat bantu untuk menyelesaikan permasalahan terkait pekerjaan proyek bidang minyak dan gas bumi seperti yang dilakukan oleh Luzon an El Sayegh [6], yang menggunakan AHP dan Delphi untuk mengidentifikasi dan mengevaluasi kriteria apa saja yang digunakan dalam pemilihan supplier pada proyek minyak dan gas bumi di United Arab Emirates (UAE). Sehingga dengan model yang dikembangkan dapat membantu perusahaan dalam memilih supplier yang terbaik, dilihat dari beberapa kriteria utama diantaranya adalah kualitas dan harga. Penelitian terkait pemilihan supplier untuk proyek minyak bumi juga dilakukan oleh Chia Nan Wang dkk [7], yaitu dengan melakukan identifikasi kriteria dan juga mengembangkan sistem pengambilan keputusan dalam pemilihan supplier dengan model Multi Criteria Decision Making (MCDM) pada proyek produksi minyak bumi di Vietnam. Dalam kasus ini AHP hnaya digunakan untuk melakukan proses evaluasi bobot dari satu set kriteria yang telah ditetapkan.

Selain diperusahaan minyak dan gas bumi metode AHP juga sering digunakan dalam bidang industri yang lain seperti yang dilakukan oleh itu Kie dkk [8] juga melakukan pendekatan dengan menggunakan AHP dalam pengambilan keputusan untuk pemilihan material studi kasus di perusahaan otomotif dengan tujuan untuk menyelidiki dan memilih bahan yang cocok untuk pembuatan peralatan troli untuk memastikan kualitas produk yang baik. Selanjutnya penelitian yang dilakukan oleh Razi, dkk [9] yaitu menggunakan AHP sebagai model pendukung keputusan dalam pemilihan kontraktor yang cocok dalam industri konstruksi di Malaysia. Dimana faktor yang digunakan adalah 3 jenis metode konstruski yaitu traditional method, design and build dan industrial building system (IBS).

Dari beberapa penelitian yang telah dilakukan ini dapat dilihat bahwa AHP memiliki potensi yang sangat baik dalam menyelesaikan suatu masalah dengan tipikal pemilihan alternatif terbaik dari satu set alternatif yang sudah tersedia. Jika dilihat lebih spesifik lagi, bahwa kasus pemilihan provider dalam mengatasi masalah kepasiran dengan metode SCON ini sangat cocok apabila didekati dengan menggunakan 
metode AHP, artinya nanti masing-masing provider dengan produknya akan dinilai dan hasil evaluasi dengan nilai tertinggi dianggap merupakan alternatif terbaik. Hal yang menjadi pembeda antara penelitian ini dengan penelitian sebelumnya adalah dari sisi objek dan lokasi penelitian, artinya secara metode memang antara penelitian yang dilakukan dengan penelitian lainnya cenderung memiliki kesamaan, akan tetapi dari sisi objek dan lokasi yang diteliti tentu akan sangat berbeda. Karena pada penelitian ini studi kasusnya adalah pada bidang minyak dan gas bumi di Indonesia dengan tujuan pengembangan sistem pengambilan keputusan MCDM menggunakan AHP untuk memilih alternatif terbaik dari satu set provider SCON yang tersedia dengan kriteria yang bersifat kuantitatif dan kualitatif.

Berdasarkan studi literatur yang telah dilakukan, memang belum ada penelitian sejenis yang spesifik menggunakan AHP sebagai metode pengambilan keputusan pemilihan provider SCON. Akan tetapi berdasarkan hasil studi yang sudah dilakukan, terlihat bahwa sudah banyak penelitian sejenis dengan tipikal permasalahan yang hampir sama yang menggunakan AHP, maka berdasarkan hal tersebut diyakini bahwa pemasalahan ini seharusnya juga bisa diselesaikan dengan metode AHP. Dengan menggunakan kriteriakriteria yang didapat dari pihak perusahaan yang selanjutnya dibobot dengan menggunakan pairwise comparison, maka akhirnya proses evaluasi penilaian untuk setiap alternatif provider bisa dilakukan dan pada akhirnya nanti akan bisa ditentukan provider terbaiknya. Dengan adanya penelitian ini diharapkan dapat diketahui parameter apa saja yang menjadi dasar pertimbangan dalam memilih provider untuk mengatasi masalah kepasiran dengan metode sand consolidation (SCON) dan didapatkannya suatu rancangan sistem pengambilan keputusan yang terukur dan bisa dipertanggungjawabkan dalam proses pemilihan provider tersebut dengan menggunakan metode AHP.

\section{Metode Penelitian}

Penelitian ini merupakan studi kasus di salah satu perusahaan pengolahan migas di Kalimantan Timur. Langkah awal adalah pembuatan struktur hierarki AHP. Dimulai dengan memahami permasalahan dan menentukan tujuan, dan juga nantinya harus memikirkan jenis mode AHP mana yang akan digunakan pada perancangan sistem, apakah distributive mode atau ideal mode. Melihat data yang ada memang hanya ada 3 provider saja yang selama ini bersaing, sehingga distributive mode dengan sistem closed dirasa lebih cocok. Akan tetapi tidak dimungkinkan jika suatu saat nanti ada tambahan provider, maka sistem ini akan diubah dalam bentuk ideal mode. Langkah selanjutnya adalah menentukan kriteria-kriteria apa saja yang mempengaruhi pemilihan provider untuk mengatasi masalah kepasiran dengan metode sand consolidation (SCON). Penentuan kriteria dan sub kriteria dilakukan dengan metode wawancara langsung dengan pihak pengambil keputusan pemilihan provider SCON. Kemudian setelah ditentukan kriteria dan sub kriteria, maka responden diminta untuk melakukan pairwise comparison sebagai data awal yang nantinya akan dikelola untuk menentukan bobot dari masing-masing kriteria dan sub kriteria. Kemudian langkah terakhir adalah dengan melakukan evaluasi penilaian terhadap masing masing alternatif provider. Artinya nanti dilakukan suatu analisa pengambilan keputusan untuk memilih alternatif provider mana yang digunakan untuk mengatasi masalah kepasiran dengan metode sand consolidation (SCON) berdasarkan nilai yang terbaik.

\subsection{Sumber Data}

Sumber utama data penelitian ini berupa data primer yang didapatkan dengan cara wawancara langsung dan pengisian kuisioner oleh para responden. Wawancara dilakukan terutama untuk mendapatkan data terkait kriteria-kriteria yang mempengaruhi pengambilan keputusan dalam pemilihan provider untuk mengatasi masalah kepasiran dengan metode sand consolidation (SCON). Sedangkan untuk data pairwise comparison kriteria dan alternatif dilakukan dengan pengisian kuisioner. Responden disini adalah para pengambil keputusan (decision maker) dari departemen Well Intervention. Total Responden berjumlah empat orang. Dimana responden merupakan profesional pada bidangnya masing-masing dan sudah berpengalaman ratarata 9-16 tahun. Sehingga dengan kualitas responden yang baik maka diharapkan data yang akan didapat juga akan valid, reliabel serta bisa dipertanggungjawabkan. Penggunaan data sekunder hanya sebagai pelengkap dalam penjelasan terkait provider dan masing-masing sub kriteria. Data sekunder nantinya berupa profil masing-masing provider, informasi mengenai produk SCON development dari masing-masing provider, serta track record hasil pekerjaan masing masing provider selama bekerjasama dengan perusahaan.

\subsection{Variabel Penelitian}

Variabel pada penelitian ini adalah satu set alternatif provider disertai produk masing-masing. Dalam menentukan provider nantinya kriteria yang digunakan antara lain adalah sebagai berikut: compatibility, harga yang ditawarkan, kualitas dari masing-masing produk tersebut, service (pelayanan), keamanan dan lingkungan serta kriteria dan sub kriteria lainnya yang akan didapat saat proses wawancara dengan pihak pengambil keputusan berlangsung.

\subsection{Analisis Data}

Analisis data pada penelitian ini adalah menggunakan metode Analytical Hierarchy Process (AHP). 
Dimana pelaksanaanya mengikuti langkah sebagai berikut:

1. Pada penelitian ini hierarki akan disusun kedalam 4 level, yaitu level 0 adalah tujuan, level 1 adalah kriteria, level 2 adalah sub kriteria dan level 3 adalah alternatif.

2. Membuat dan menyusun matriks perbandingan berpasangan antar kriteria

3. Melakukan pembobotan matriks perbandingan berpasangan untuk masing masing kriteria (level 1).

4. Membuat matriks perbandingan berpasangan untuk masing-masing level 2 (antar sub kriteria).

5. Melakukan pembobotan perbandingan berpasangan untuk masing-masing level 3 (antar alternatif) untuk tiap sub kriteria.

6. Melakukan perhitungan nilai eigen dan menguji konsistensi matriks berpasangan yang sudah dibuat menggunakan rumus:

$$
C I=\frac{\lambda_{m a k s}-n}{n-1}
$$

Dimana, $\mathrm{CI}$ adalah indeks konsistensi; $\lambda_{\text {maks }}$ adalah eigen value maksimum; dan $\mathrm{n}$ adalah orde matriks.

$$
C R=\frac{C I}{R I}
$$

Dimana CR adalah rasio konsistensi dan RI adalah indeks random [10].

7. Menghitung bobot prioritas untuk masing-masing alternatif tersebut sehingga didapatkan nilai pembobotan untuk penentuan prioritas akhir.

\subsection{Diagram Alir Penelitian}

Dalam rangka untuk memperjelas langkah langkah penelitian yang dilakukan maka pada Gambar 1 ditampilkan diagram alir penelitian.
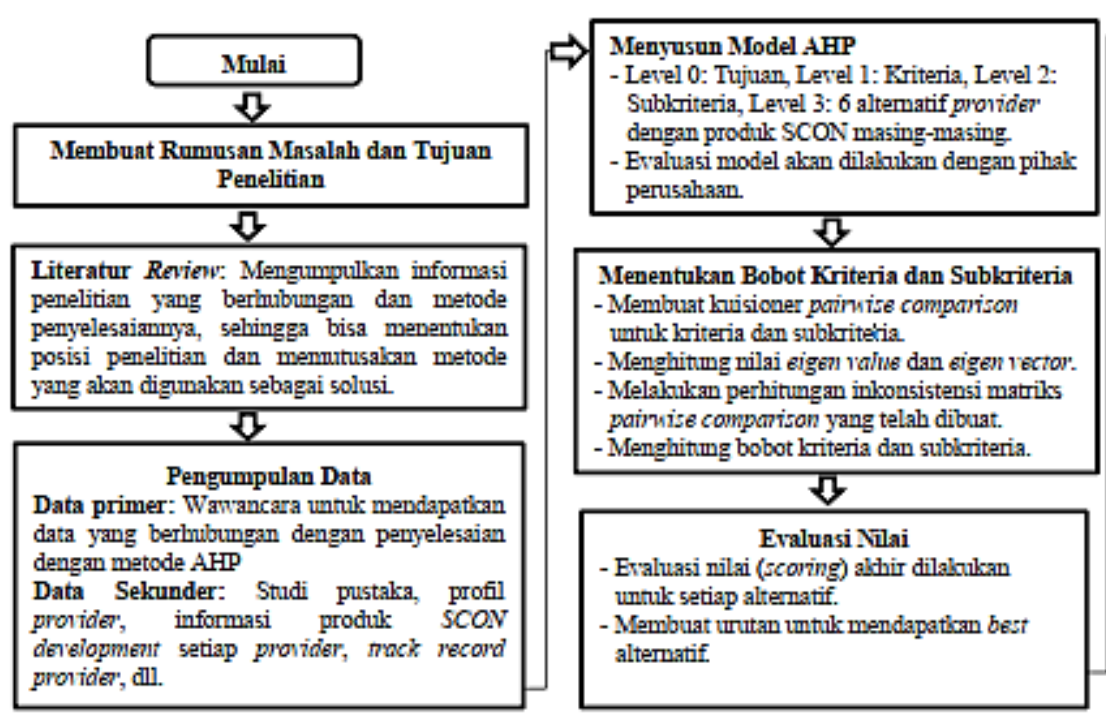

Gambar 1. Diagram Alir Penelitian

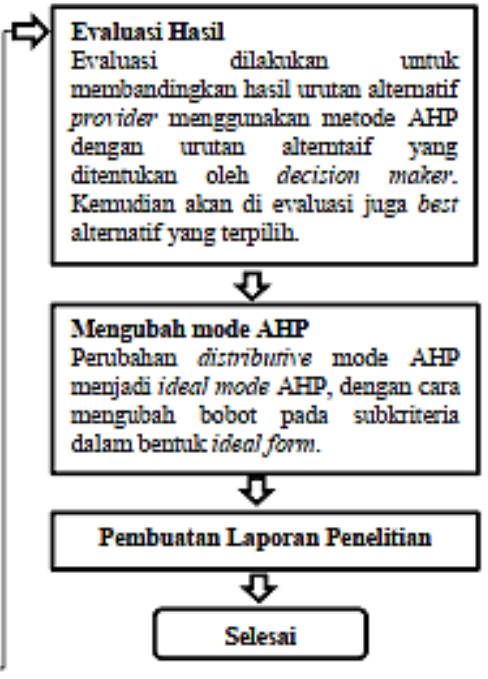

Mengubah mode AHP

Perubahan aistriburive mode AHP menadicing dalam bentuk ideal form.

Pembuatan Laporan Penelitian Selesai

\section{Hasil dan Pembahasan}

\subsection{Struktur Hierarki}

Dalam menyusun struktur hierarki, diperlukan informasi sebanyak mungkin agar memudahkan dalam memetakan permasalahan tersebut kedalam bentuk level-level terstruktur. Pada penelitian ini, pengumpulan informasi dilakukan dengan mewawancarai 4 responden yang merupakan profesional pada bidang tersebut. Informasi yang diperoleh akan disusun menjadi parameter yang akan digunakan pada model AHP. Struktur hierarki yang digunakan ditampilkan pada Gambar 2. Struktur hierarki ini terdiri dari tujuan, kriteria, sub kriteria dan alternatif. 


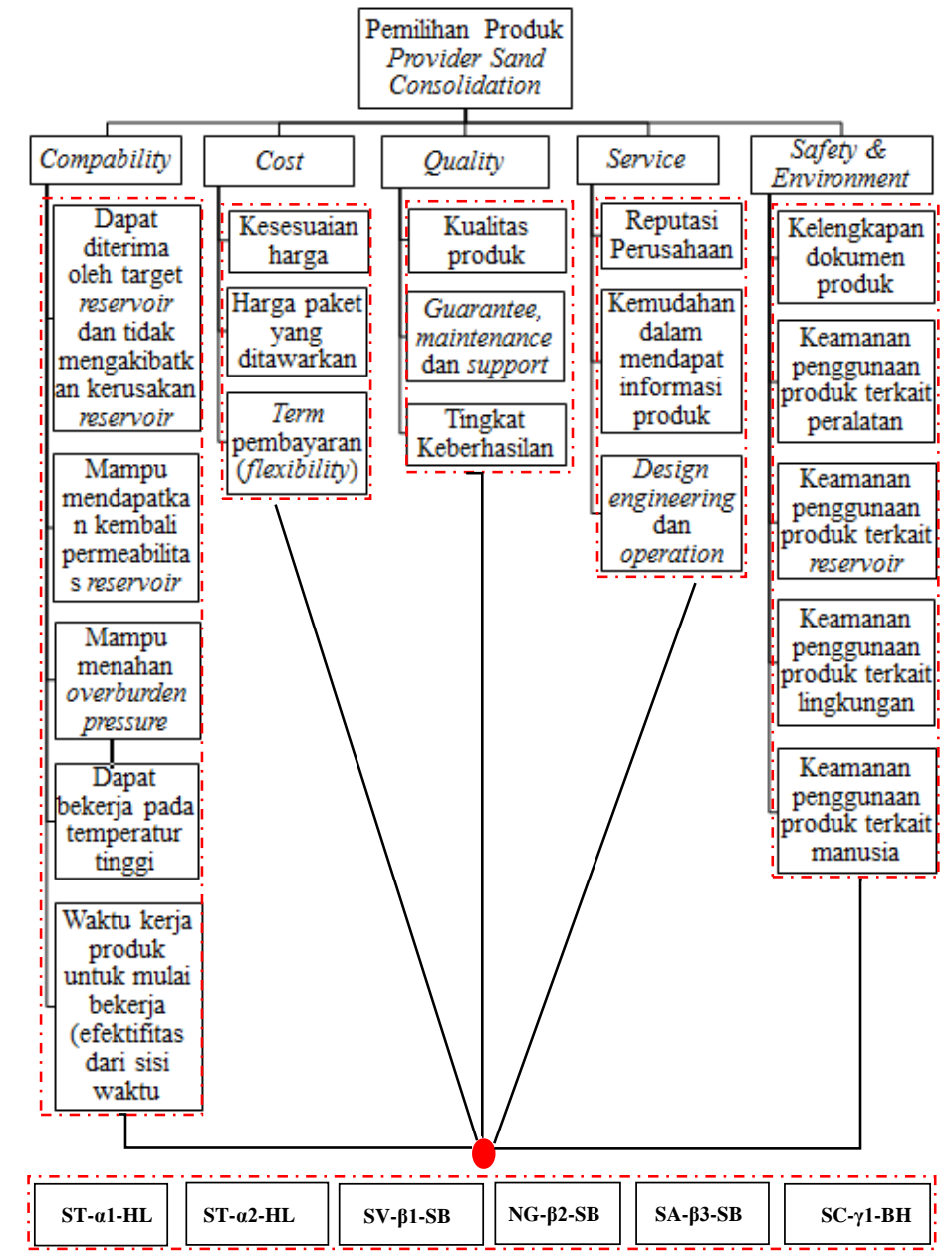

Gambar 2. Struktur hierarki pemilihan produk provider sand consolidation

Terdapat 4 level struktur hierarki pada pemilihan produk provider sand consolidation. Level pertama merupakan tujuan untuk memilih produk provider mana yang akan digunakan dalam mengatasi masalah kepasiran dengan metode sand consolidation. Level kedua merupakan kriteria utama, dimana kriteria ini akan mempengaruhi decision maker dalam mengambil keputusan. Kriteria utama terdiri dari 5 kriteria yaitu, compability, cost, quality, service dan safety \& environment. Pada level ketiga ini berupa parameter yang berkaitan langsung dengan provider dan merupakan turunan dari kriteria utama. Level 3 terdiri dari, 5 sub kriteria compability, 3 sub kriteria cost, 3 sub kriteria quality, 4 sub kriteria service dan 5 sub kriteria safety \& environment. Pada level 4 (bagian terakhir dari struktur AHP) yaitu produk provider yang menjadi alternatif dalam mengatasi masalah kepasiran. Produk provider ini akan dinilai berdasarkan parameter pada level 4, kemudian hasil penilaian ini akan dijadikan penentuan produk provider mana yang akan digunakan untuk mengatasi masalah kepasiran.

\subsection{Perhitungan Bobot Kriteria}

Untuk mengetahui tingkat kepentingan dari suatu kriteria maka dilakukan perbandingan antar masingmasing kriteria. Terdapat 5 kriteria yang dibandingkan yaitu compability, cost, quality, service dan safety \& environment. Hasil pengolahan kuisioner dalam bentuk perbandingan berpasangan ditampilkan pada Tabel 1.

Tabel 1. Nilai perbandingan berpasangan kriteria

\begin{tabular}{cccccc}
\hline Kriteria & Compatibility & Cost & Quality & Service & Safety \& Environment \\
\hline Compatibility & 1 & 2 & 3 & 5 & 1 \\
Cost & $1 / 2$ & 1 & $1 / 3$ & 1 & 1 \\
Quality & $1 / 3$ & 3 & 1 & 3 & 1 \\
Service & $1 / 5$ & 1 & $1 / 3$ & 1 & $1 / 4$ \\
Safety \& Environment & 1 & 1 & 1 & 4 & 1 \\
\hline
\end{tabular}


Selanjutnya, dari Tabel 1 dibuat sebuah matriks berpasangan $5 \times 5$ untuk mencari eigen value $(\lambda)$ dan eigen vektor $(w)$. Hasil dari eigen value dan eigen vector ditampilkan pada Tabel 2.

Tabel 2. Eigen vektor dan eigen value kriteria

\begin{tabular}{ccc} 
Kriteria & Eigen Vektor & Eigen Value \\
\hline Compatibility & 0,349 & \\
Cost & 0,127 & \\
Quality & 0,219 & 5,346 \\
Service & 0,075 & \\
Safety \& Environment & 0,229 &
\end{tabular}

Setelah dilakukan perhitungan, maka dapat diketahui nilai eigen value ( $\lambda$ maks) dari matriks perbandingan berpasangan pada tabel 1 yaitu sebesar 5,346 (ditampilkan pada Tabel 2). Nilai eigen value digunakan untuk melakukan pengukuran konsistensi. Suatu matriks perbandingan berpasangan dinyatakan konsisten jika nilai CR yang diperoleh tidak lebih dari $0,1(\mathrm{CR} \leq 0,1)[11]$.

$$
\begin{gathered}
C I=\frac{5,346-5}{4}=0,087 \\
C R=\frac{0,039}{1,12}=0,077
\end{gathered}
$$

Terlihat bahwa nilai $\mathrm{CR}$ yang didapat adalah $\leq 0,1$ maka matriks perbandingan berpasangan pada Tabel 1 dapat diterima atau konsisten.

Selanjutnya bisa dilakukan perhitungan bobot dari masing-masing kriteria dengan menghitung nilai eigen vektornya. Dimana hasil perhitungam eigen vektor merupakan urutan tingkat kepentingan kriteria yang digunakan dalam pemilihan provider SCON yaitu, compatibility $(0,349)$, safety \& environment $(0,229)$, quality $(0,219)$, cost $(0,127)$, dan service $(0,075)$. Total jumlah bobot harus berjumlah 1 .

\subsection{Perhitungan Bobot Sub kriteria}

Perhitungan bobot sub kriteria dilakukan untuk membandingkan setiap sub kriteria yang telah ditentukan. Jumlah sub kriteria pada setiap kriteria berbeda-beda. Hasil dari kuisioner didapatkan nilai perbandingan berpasangan untuk masing-masing sub kriteria compatibility. Maka selanjutnya adalah menghitung eigen value dan melakukan pengukuran konsistensi matriks perbandingan berpasangan, setelah itu baru menghitung nilai eigen vektor untuk mendapatkan nilai bobot dari masing-masing sub kriteria compatibility.

a. Compatibility

Hasil perhitungan dari sub kriteria compatibility ditampilkan pada Tabel 3.

\begin{tabular}{|c|c|c|c|c|c|c|}
\hline $\begin{array}{c}\text { Sub } \\
\text { kriteria }\end{array}$ & $\begin{array}{l}\text { Dapat diterima oleh } \\
\text { target reservoir dan } \\
\text { tidak } \\
\text { mengakibatkan } \\
\text { kerusakan reservoir } \\
\text { (A) }\end{array}$ & $\begin{array}{l}\text { Mampu } \\
\text { mendapatkan } \\
\text { kembali } \\
\text { permebealitas } \\
\text { reservoir } \\
\text { (B) }\end{array}$ & $\begin{array}{l}\text { Mampu } \\
\text { menahan } \\
\text { overburden } \\
\text { pressure } \\
\text { (C) }\end{array}$ & $\begin{array}{c}\text { Dapat } \\
\text { bekerja pada } \\
\text { temperature } \\
\text { tinggi } \\
\text { (D) }\end{array}$ & $\begin{array}{l}\text { Waktu kerja } \\
\text { produk untuk } \\
\text { mulai bekerja } \\
\text { (efektifitas dari } \\
\text { sisi waktu) } \\
\text { (E) }\end{array}$ & $\begin{array}{l}\text { Eigen } \\
\text { Vektor }\end{array}$ \\
\hline A & 1 & 1 & 2 & 5 & 5 & 0,360 \\
\hline B & 1 & 1 & 4 & 3 & 4 & 0,340 \\
\hline $\mathrm{C}$ & $1 / 2$ & $1 / 4$ & 1 & $1 / 2$ & 2 & 0,109 \\
\hline $\mathrm{D}$ & $1 / 5$ & $1 / 3$ & 2 & 1 & 2 & 0,126 \\
\hline $\mathrm{E}$ & $1 / 5$ & $1 / 4$ & $1 / 2$ & $1 / 2$ & 1 & 0,065 \\
\hline \multicolumn{6}{|c|}{ Eigen Value } & 5,215 \\
\hline \multicolumn{6}{|c|}{ Consistency Index (CI) } & 0,054 \\
\hline \multicolumn{6}{|c|}{ Consistency Ratio (CR) } & 0,048 \\
\hline
\end{tabular}

Tabel 3. Nilai perbandingan berpasangan, eigen vektor, dan eigen value sub kriteria compatibility

Pada Tabel 3, berdasarkan perhitungan didapat nilai eigen value adalah 5,215, sehingga nilai CI adalah 0,054 dan nilai CR adalah $0,048(\leq 0,1)$, artinya matriks perbandingan berpasangan untuk sub kriteria compatibility merupakan matriks yang konsisten sehingga tidak perlu dilakukan evaluasi perbaikan nilai matriks perbandingan berpasangannya. Selanjutnya berdasarkan perhitungan didapat nilai eigen vektor masing-masing sub kriteria, dengan mengetahui nilai eigen vektor ini makan didapat bobot urutan sub kriteria compatibility mulai dari nilai tertinggi yaitu, dapat diterima oleh target reservoir dan tidak mengakibatkan kerusakan reservoir $(0,360)$, mampu mendapatkan kembali permebealitas reservoir $(0,340)$, dapat bekerja pada temperature tinggi $(0,126)$, mampu menahan overburden pressure $(0,109)$, waktu kerja 
Pemilihan Provider Sand Consolidation dengan Metode Analytical Hierarchy Process

produk untuk mulai bekerja (efektifitas dari sisi waktu) (0,065). Serta didapatkan nilai CR $\leq \mathbf{0 , 1}$ maka dapat diterima atau konsisten.

b. Cost

Hasil perhitungan dari sub kriteria cost ditampilkan pada Tabel 4.

Tabel 4. Nilai perbandingan berpasangan, eigen vektor, dan eigen value sub kriteria cost

\begin{tabular}{ccccc}
\hline $\begin{array}{c}\text { Sub } \\
\text { kriteria }\end{array}$ & $\begin{array}{c}\text { Kesesuaian harga } \\
\text { penawaran } \\
(\mathrm{A})\end{array}$ & $\begin{array}{c}\text { Harga paket yang } \\
\text { ditawarkan } \\
(\mathrm{B})\end{array}$ & $\begin{array}{c}\text { Term pembayaran } \\
\text { flexibility) } \\
(\mathrm{C})\end{array}$ & $\begin{array}{c}\text { Eigen } \\
\text { Vektor }\end{array}$ \\
\hline $\mathrm{A}$ & 1 & $1 / 2$ & 2 & 0,270 \\
$\mathrm{~B}$ & 2 & 1 & 3 & 0,540 \\
$\mathrm{C}$ & $1 / 2$ & $1 / 3$ & 1 & 0,163 \\
\hline \multicolumn{5}{c}{ Consistency Index $(\mathrm{CI})$} \\
\hline
\end{tabular}

Pada Tabel 4, berdasarkan perhitungan didapat nilai eigen value adalah 3,009, sehingga nilai CI adalah 0,005 dan nilai $\mathrm{CR}$ adalah $0,008(\leq \mathbf{0 , 1})$, artinya matriks perbandingan berpasangan $(\mathbf{3 x} 3)$ untuk sub kriteria cost merupakan matriks yang konsisten sehingga tidak perlu dilakukan evaluasi perbaikan nilai matriks perbandingan berpasangannya. Selanjutnya berdasarkan perhitungan didapat nilai eigen vektor masing-masing sub kriteria, dengan mengetahui nilai eigen vektor ini makan didapat bobot urutan sub kriteria cost mulai dari nilai tertinggi yaitu harga paket yang ditawarkan $(0,540)$, Kesesuaian harga penawaran $(0,270)$, dan term pembayaran (flexibility) $(0,163)$.

c. Quality

Hasil perhitungan dari sub kriteria quality ditampilkan pada Tabel 5.

Tabel 5. Nilai perbandingan berpasangan, eigen vektor, dan eigen value sub kriteria quality

\begin{tabular}{ccccc}
\hline Sub kriteria & $\begin{array}{c}\text { Kualitas } \\
\text { Produk } \\
\text { (A) }\end{array}$ & $\begin{array}{c}\text { Guarantee, maintenance dan } \\
\text { support } \\
\text { (B) }\end{array}$ & $\begin{array}{c}\text { Tingkat keberhasilan } \\
\text { (C) }\end{array}$ & Eigen Vektor \\
\hline $\mathrm{A}$ & 1 & 5 & $1 / 3$ & 0,287 \\
$\mathrm{~B}$ & $1 / 5$ & 1 & $1 / 6$ & 0,078 \\
$\mathrm{C}$ & 3 & 6 & 1 & 0,635 \\
\hline & \multicolumn{5}{c}{ Eigen Value } & 3,094 \\
\hline & Consistency Index $(\mathrm{CI})$ & 0,047 \\
\hline
\end{tabular}

Pada Tabel 5, berdasarkan perhitungan didapat nilai eigen value adalah 3,094, sehingga nilai CI adalah 0,047 dan nilai CR adalah $0,081(\leq 0,1)$,artinya matriks perbandingan berpasangan $(3 \times 3)$ untuk sub kriteria cost merupakan matriks yang konsisten sehingga tidak perlu dilakukan evaluasi perbaikan nilai matriks perbandingan berpasangannya. Selanjutnya berdasarkan perhitungan didapat nilai eigen vektor masingmasing sub kriteria, dengan mengetahui nilai eigen vektor ini makan didapat bobot urutan sub kriteria quality mulai dari nilai tertinggi yaitu tingkat keberhasilan $(0,635)$, kualitas produk $(0,287)$, guarantee, maintenance dan support $(0,078)$.

d. Service

Hasil perhitungan dari sub kriteria service ditampilkan pada Tabel 6.

Tabel 6. Nilai perbandingan berpasangan, eigen vektor, dan eigen value sub kriteria service

\begin{tabular}{cccccc}
\hline $\begin{array}{c}\text { Sub } \\
\text { kriteria }\end{array}$ & $\begin{array}{c}\text { Reputasi } \\
\text { Perusahaan } \\
(\mathrm{A})\end{array}$ & $\begin{array}{c}\text { Kemudahan dalam } \\
\text { mendapat informasi produk } \\
(\mathrm{B})\end{array}$ & $\begin{array}{c}\text { Kecepatan } \\
\text { Merespon } \\
(\mathrm{C})\end{array}$ & $\begin{array}{c}\text { Design engineering } \\
\text { dan operation } \\
(\mathrm{D})\end{array}$ & $\begin{array}{c}\text { Eigen } \\
\text { Vektor }\end{array}$ \\
\hline $\mathrm{A}$ & 1 & 3 & 4 & $1 / 4$ & 0,255 \\
$\mathrm{~B}$ & $1 / 3$ & 1 & 1 & $1 / 5$ & 0,092 \\
$\mathrm{C}$ & $1 / 4$ & 1 & 1 & $1 / 3$ & 0,104 \\
$\mathrm{D}$ & 4 & 5 & 3 & 0,550 \\
\hline \multicolumn{7}{c}{ Consistency Index $(\mathrm{CI})$} \\
\hline \multicolumn{7}{c}{ Consistency Ratio $(\mathrm{CR})$} \\
\hline
\end{tabular}


Pada Tabel 6, berdasarkan perhitungan didapat nilai eigen value adalah 4,256, sehingga nilai CI adalah 0,085 dan nilai $\mathrm{CR}$ adalah $0,095(\leq 0,1)$, artinya matriks perbandingan berpasangan $(4 \times 4)$ untuk sub kriteria service merupakan matriks yang konsisten sehingga tidak perlu dilakukan evaluasi perbaikan nilai matriks perbandingan berpasangannya. Selanjutnya berdasarkan perhitungan didapat nilai eigen vektor masingmasing sub kriteria, dengan mengetahui nilai eigen vektor ini makan didapat bobot urutan sub kriteria service mulai dari nilai tertinggi yaitu design engineering dan operation $(0,550)$, reputasi perusahaan $(0,225)$, kecepatan merespon $(0,104)$ dan kemudahan dalam mendapat informasi produk $(0,092)$.

e. Safety \& Environment

Hasil perhitungan dari sub kriteria safety \& environment ditampilkan pada Tabel 7.

Tabel 7. Nilai perbandingan berpasangan, eigen vektor, dan eigen value sub kriteria safety \& environment

\begin{tabular}{ccccccc}
\hline $\begin{array}{c}\text { Sub } \\
\text { kriteria }\end{array}$ & $\begin{array}{c}\text { Ketersedian } \\
\text { HSE } \\
\text { dokumen } \\
\text { produk } \\
(\mathrm{A})\end{array}$ & $\begin{array}{c}\text { Keamanan } \\
\text { penggunaan } \\
\text { produk terkait } \\
\text { peralatan } \\
(\mathrm{B})\end{array}$ & $\begin{array}{c}\text { Keamanan } \\
\text { penggunaan } \\
\text { produk terkait } \\
\text { reservoir } \\
(\mathrm{C})\end{array}$ & $\begin{array}{c}\text { Keamanan } \\
\text { penggunaan } \\
\text { produk terkait } \\
\text { lingkungan } \\
(\mathrm{D})\end{array}$ & $\begin{array}{c}\text { Keamanan } \\
\text { penggunaan } \\
\text { produk terkait } \\
\text { manusia } \\
(\mathrm{E})\end{array}$ & $\begin{array}{c}\text { Eigen } \\
\text { Vektor }\end{array}$ \\
\hline $\mathrm{A}$ & 1 & $1 / 3$ & $1 / 3$ & $1 / 5$ & $1 / 5$ & 0,051 \\
$\mathrm{~B}$ & 3 & 1 & $1 / 3$ & $1 / 3$ & $1 / 3$ & 0,100 \\
$\mathrm{C}$ & 3 & 3 & 3 & $1 / 3$ & $1 / 3$ & 0,157 \\
$\mathrm{D}$ & 5 & 3 & 3 & $1 / 3$ & 0,269 \\
$\mathrm{E}$ & 5 & 3 & 3 & 1 & 0,422 \\
\hline \multicolumn{7}{c}{ Eigen Value } \\
\hline \multicolumn{7}{c}{ Consistency Index $(\mathrm{CI})$} \\
\hline
\end{tabular}

Pada Tabel 7, berdasarkan perhitungan didapat nilai eigen value adalah 5,355, sehingga nilai CI adalah 0,089 dan nilai $\mathrm{CR}$ adalah $0,079(\leq 0,1)$, artinya matriks perbandingan berpasangan $(5 \times 5)$ untuk sub kriteria safety \& environment merupakan matriks yang konsisten sehingga tidak perlu dilakukan evaluasi perbaikan nilai matriks perbandingan berpasangannya. Selanjutnya berdasarkan perhitungan didapat nilai eigen vektor masing-masing sub kriteria, dengan mengetahui nilai eigen vektor ini makan didapat bobot urutan sub kriteria safety \& environment mulai dari nilai tertinggi yaitu keamanan penggunaan produk terkait manusia $(0,422)$, keamanan penggunaan produk terkait lingkungan $(0,269)$, keamanan penggunaan produk terkait reservoir $(0,157)$ keamanan penggunaan produk terkait peralatan $(0,100)$, ketersedian HSE dokumen produk $(0,051)$

\subsection{Perhitungan Bobot Alternatif}

Perhitungan bobot alternatif dilakukan untuk membandingkan masing-masing dari alternatif yang telah ditentukan sebelumnya. Terdapat 6 alternatif yang digunakan yaitu, ST- $\alpha 1-H L, S T-\alpha 2-H L, S V-\beta 1-S B$, NG- $\beta 2-S B$, SA- $\beta 2-S B$, dan SC- $\gamma 1-B H$. Perhitungan nilai bobot dilakukan pada masing-masing sub kriteria dan alternatif. Berikut hasil perhitungannya.

\section{a. Kriteria compatibility}

1. Dapat diterima oleh target dan tidak mengakibatkan kerusakan reservoir (kode A)

2. Mampu mendapatkan kembali permebealitas reservoir (kode B)

3. Mampu menahan overburden pressure (kode C)

4. Dapat bekerja pada temperature tinggi (kode D)

5. Waktu kerja produk untuk mulai bekerja (efektifitas dari sisi waktu) (kode E)

Tabel 8. Nilai alternatif pada sub kriteria compatibility

\begin{tabular}{|c|c|c|c|c|c|c|}
\hline & 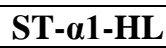 & ST- $\alpha 2-H L$ & 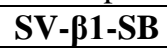 & NG-ß32-SB & SA-ß32-SB & SC- $\gamma 1-B H$ \\
\hline $\mathbf{A}$ & 0,054 & 0,350 & 0,229 & 0,126 & 0,043 & 0,198 \\
\hline B & 0,054 & 0,353 & 0,229 & 0,122 & 0,042 & 0,201 \\
\hline $\mathrm{C}$ & 0,041 & 0,238 & 0,231 & 0,198 & 0,035 & 0,257 \\
\hline D & 0,182 & 0,24 & 0,066 & 0,137 & 0,123 & 0,253 \\
\hline $\mathbf{E}$ & 0,184 & 0,271 & 0,126 & 0,109 & 0,104 & 0,205 \\
\hline
\end{tabular}

Pada Tabel 8, berdasarkan perhitungan didapat bahwa pada sub kriteria A alternatif ST- $\alpha 2-\mathrm{HL}$ merupakan nilai tertinggi yaitu $(0,350)$, sub kriteria B alternatif ST- $\alpha 2-H L$ merupakan nilai tertinggi yaitu $(0,353)$, sub kriteria $\mathrm{C}$ alternatif SC- $\gamma 1-\mathrm{BH}$ merupakan nilai tertinggi yaitu $(0,257)$, sub kriteria D alternatif SC- $\gamma 1-\mathrm{BH}$ merupakan nilai tertinggi yaitu $(0,253)$, sub kriteria E alternatif ST- $\alpha 2-\mathrm{HL}$ merupakan nilai tertinggi yaitu $(0,271)$. 


\section{b. Kriteria cost}

1. Kesesuaian harga penawaran (kode $\mathrm{A})$

2. Harga paket yang ditawarkan (kode B)

3. Term pembayaran (flexibility) (kode C)

Tabel 9. Nilai alternatif pada sub kriteria cost

\begin{tabular}{|c|c|c|c|c|c|c|}
\hline & ST-a1-HL & ST- $\alpha 2-H L$ & SV- $\beta 1-S B$ & NG-B2-SB & SA- $\beta 2-S B$ & SC- $\gamma 1-B H$ \\
\hline $\mathbf{A}$ & 0,154 & 0,305 & 0,154 & 0,069 & 0,075 & 0,243 \\
\hline B & 0,19 & 0,29 & 0,126 & 0,077 & 0,069 & 0,248 \\
\hline C & 0,292 & 0,297 & 0,089 & 0,085 & 0,089 & 0,149 \\
\hline
\end{tabular}

Pada Tabel 9, berdasarkan perhitungan didapat bahwa pada sub kriteria A alternatif ST- $\alpha 2-\mathrm{HL}$ merupakan nilai tertinggi yaitu $(0,305)$, sub kriteria B alternatif ST- $\alpha 2-H L$ merupakan nilai tertinggi yaitu $(0,29)$, sub kriteria C alternatif ST- $\alpha 2-$ HL merupakan nilai tertinggi yaitu $(0,297)$.

\section{c. Kriteria qualility}

1. Kualitas produk (kode A)

2. Guarantee, maintenance \& support (kode B)

3. Tingkat keberhasilan (kode $\mathrm{C}$ )

Tabel 10. Nilai alternatif pada sub kriteria qualility

\begin{tabular}{|c|c|c|c|c|c|c|}
\hline & ST- $\alpha 1-H L$ & ST- $\alpha 2-H L$ & SV- $\beta 1-S B$ & NG- $\beta 2-S B$ & SA-ß2-SB & SC- $\gamma 1-B H$ \\
\hline $\mathbf{A}$ & 0,129 & 0,294 & 0,239 & 0,117 & 0,052 & 0,17 \\
\hline B & 0,217 & 0,365 & 0,089 & 0,089 & 0,095 & 0,146 \\
\hline C & 0,118 & 0,318 & 0,201 & 0,066 & 0,074 & 0,224 \\
\hline
\end{tabular}

Pada Tabel 10, berdasarkan perhitungan didapat bahwa pada sub kriteria A alternatif ST- $\alpha 2-\mathrm{HL}$ merupakan nilai tertinggi yaitu $(0,294)$, sub kriteria B alternatif ST- $\alpha 2-H L$ merupakan nilai tertinggi yaitu $(0,365)$, sub kriteria C alternatif ST- $\alpha 2-H L$ merupakan nilai tertinggi yaitu $(0,318)$.

\section{d. Kriteria service}

1. Reputasi perusahaan (kode A)

2. Kemudahan dalam mendapat informasi produk (kode B)

3. Kecepatan merespon (kode C)

4. Design engineering \& operation (kode D)

Tabel 11. Nilai bobot alternatif pada sub kriteria service

\begin{tabular}{|c|c|c|c|c|c|c|}
\hline & ST-a1-HL & ST- $\alpha 2-H L$ & 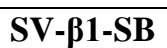 & NG-B2-SB & SA-B2-SB & SC- $\gamma 1-B H$ \\
\hline $\mathbf{A}$ & 0,188 & 0,188 & 0,164 & 0,148 & 0,148 & 0,164 \\
\hline B & 0,167 & 0,167 & 0,167 & 0,167 & 0,167 & 0,167 \\
\hline $\mathrm{C}$ & 0,177 & 0,385 & 0,121 & 0,058 & 0,103 & 0,155 \\
\hline D & 0,146 & 0,292 & 0,186 & 0,085 & 0,081 & 0,209 \\
\hline
\end{tabular}

Pada Tabel 11, berdasarkan perhitungan didapat bahwa pada sub kriteria A alternatif ST- $\alpha 2-H L$ dan ST- $\alpha 1$-HL merupakan nilai tertinggi yaitu $(0,188)$, sub kriteria B tidak ada alternatif terbaik karena semua alternatif memiliki nilai yang sama yaitu $(0,167)$, sub kriteria $C$ alternatif ST- $\alpha 2-H L$ merupakan nilai tertinggi yaitu $(0,385)$, sub kriteria D alternatif ST- $\alpha 2-H L$ merupakan nilai tertinggi yaitu $(0,292)$.

\section{e. Kriteria safety \& environment}

1. Ketersedian HSE dokumen produk (kode A)

2. Keamanan penggunaan produk terkait peralatan (kode B)

3. Keamanan penggunaan produk terkait reservoir (kode C)

4. Keamanan penggunaan produk terkait lingkungan (kode D)

5. Keamanan penggunaan produk terkait manusia (kode E)

Tabel 12. Nilai alternatif pada sub kriteria safety \& environment

\begin{tabular}{|c|c|c|c|c|c|c|}
\hline & ST-a1-HL & ST-a2-HL & 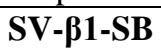 & NG- $\beta 2-S B$ & SA-B2-SB & SC- $\gamma 1-B H$ \\
\hline $\mathbf{A}$ & 0,167 & 0,167 & 0,167 & 0,167 & 0,167 & 0,167 \\
\hline B & 0,182 & 0,204 & 0,162 & 0,116 & 0,128 & 0,209 \\
\hline C & 0,187 & 0,211 & 0,163 & 0,146 & 0,146 & 0,148 \\
\hline D & 0,184 & 0,184 & 0,163 & 0,132 & 0,147 & 0,189 \\
\hline $\mathbf{E}$ & 0,188 & 0,188 & 0,164 & 0,148 & 0,148 & 0,164 \\
\hline
\end{tabular}

Pada Tabel 11, berdasarkan perhitungan didapat bahwa pada sub kriteria A tidak ada alternatif terbaik karena semua alternatif memiliki nilai yang sama yaitu $(0,167)$, sub kriteria B alternatif ST- $\alpha 2-\mathrm{HL}$ merupakan nilai tertinggi yaitu $(0,204)$, sub kriteria C alternatif ST- $\alpha 2-H L$ merupakan nilai tertinggi yaitu 
$(0,211)$, sub kriteria D alternatif SC- $\gamma 1-\mathrm{BH}$ merupakan nilai tertinggi yaitu $(0,189)$, sub kriteria $\mathrm{D}$ alternatif ST- $\alpha 2-H L$ dan SC- $\gamma 1-B H$ merupakan nilai tertinggi yaitu $(0,188)$.

Setelah mengetahui nilai masing-masing alternatif terhadap semua sub kriteria, maka selanjutnya kita bisa menghitung nilai alternatif terhadap kriteria, dengan cara menjumlahkan semua nilai alternatif pada semua sub kriteria yang berhubungan langsung dengan setiap kriterianya. Sebagai contoh kita akan menghitung weight score alternatif ST- $\alpha 1-\mathrm{HL}$ untuk kriteria compatibility. Dari data Tabel 8, dilihat bahwa dengan mengalikan setiap nilai pada kolom ST- $\alpha 1-\mathrm{HL}$ dengan nilai bobot untuk masing-masing sub kriteria pada Tabel 3 maka didapat weight score, yaitu :

$(0,054 * 0,36)+(0,054 * 0,34)+(0,041 * 0,109)+(0,182 * 0,126)+(0,184 * 0,065)=0,0194+0,0184+0,0045+$ $0,229+0,012=0,077$. Berikut hasil perhitungan weight score untuk setiap alternatif pada masing-masing kriteria:

\section{a. Kriteria compatibility}

Hasil perhitungan dari alternatif pada kriteria compatibility ditampilkan pada Tabel 13.

Tabel 13. Nilai weight score pada kriteria compatibility

\begin{tabular}{|c|c|c|c|c|c|c|}
\hline Alternatif & 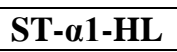 & ST- $\alpha 2-H L$ & SV- $\beta 1-S B$ & NG- $\beta 2-S B$ & SA- $\boldsymbol{\beta 2}-\mathrm{SB}$ & SC- $\gamma 1-B H$ \\
\hline Kriteria Compatibility & 0,077 & 0,320 & 0,202 & 0,133 & 0,056 & 0,213 \\
\hline
\end{tabular}

Berdasarkan nilai bobot yang didapatkan dari hasil perhitungan pada Tabel 13, maka dapat diketahui urutan alternatif provider untuk kriteria compatibility mulai dari nilai tertinggi yaitu, ST- $\alpha 2$-HL $(0,320)$, SC$\gamma 1$-BH $(0,213)$, SV- $\beta 1$-SB $(0,202)$, NG- $\beta 2-S B(0,133)$, ST- $\alpha 1$-HL $(0,077)$, dan SA- $\beta 2-S B(0,056)$.

b. Kriteria cost

Hasil perhitungan dari alternatif pada kriteria cost ditampilkan pada Tabel 14.

Tabel 14. Nilai weight score pada kriteria cost

\begin{tabular}{|c|c|c|c|c|c|c|}
\hline Altern & ST- $\alpha 1-H L$ & ST- $\alpha 2-H L$ & SV- $\beta 1-S B$ & 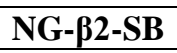 & SA- $\beta 2-S B$ & SC- $\gamma 1-B H$ \\
\hline iteria Cost & 0,196 & 0,295 & 0,128 & 0,076 & 0,074 & 0,23 \\
\hline
\end{tabular}

Berdasarkan nilai bobot yang didapatkan dari hasil perhitungan pada Tabel 14, maka dapat diketahui urutan alternatif provider untuk kriteria cost mulai dari nilai tertinggi yaitu, ST- $\alpha 2-\mathrm{HL}(0,295)$, SC- $\gamma 1-\mathrm{BH}$ $(0,230)$, ST- $\alpha 1-H L(0,196)$, SV- $\beta 1-S B(0,128)$, NG- $\beta 2-S B(0,076)$, dan SA- $\beta 2-S B(0,074)$.

\section{c. Kriteria Quality}

Hasil perhitungan dari alternatif pada kriteria quality ditampilkan pada Tabel 15.

Tabel 15. Nilai weight score pada kriteria quality

\begin{tabular}{|c|c|c|c|c|c|c|}
\hline Alternatif & ST-a1-HL & ST- $\alpha 2-H L$ & SV- $\beta 1-S B$ & NG- $\beta 2-S B$ & SA- $\beta 2-S B$ & SC- $\gamma 1-\mathrm{BH}$ \\
\hline $\begin{array}{l}\text { Kriteria } \\
\text { Quality }\end{array}$ & 0,129 & 0,315 & 0,203 & 0,083 & 0,069 & 0,202 \\
\hline
\end{tabular}

Berdasarkan nilai bobot yang didapatkan dari hasil perhitungan pada Tabel 15, maka dapat diketahui urutan alternatif provider untuk kriteria quality mulai dari nilai tertinggi yaitu, ST- $\alpha 2-\mathrm{HL}(0,315), \mathrm{SV}-\beta 1-\mathrm{SB}$ $(0,203)$, SC- $\gamma 1-\mathrm{BH}(0,202), \mathrm{ST}-\alpha 1-\mathrm{HL}(0,129)$, NG- $\beta 2-\mathrm{SB}(0,083)$, dan SA- $\beta 2-\mathrm{SB}(0,069)$.

\section{d. Kriteria service}

Hasil perhitungan dari alternatif pada kriteria service ditampilkan pada Tabel 16.

Tabel 16. Nilai weight score pada kriteria service

\begin{tabular}{|c|c|c|c|c|c|c|}
\hline Alternatif & ST- $\alpha 1-H L$ & ST- $\alpha 2-H L$ & SV- $\beta 1-S B$ & NG-ק2-SB & SA-ß32-SB & SC- $\gamma 1-B H$ \\
\hline Kriteria Service & 0,162 & 0,264 & 0,172 & 0,106 & 0,109 & 0,188 \\
\hline
\end{tabular}

Berdasarkan nilai bobot yang didapatkan dari hasil perhitungan pada Tabel 16, maka dapat diketahui urutan alternatif provider untuk kriteria quality mulai dari nilai tertinggi yaitu, ST- $\alpha 2-\mathrm{HL}(0,264)$, SC- $\gamma 1-\mathrm{BH}$ $(0,188)$, SV- $\beta 1$-SB $(0,172)$, ST- $\alpha 1-H L(0,162)$, SA- $\beta 2-S B(0,109)$, dan NG- $\beta 2-S B(0,106)$.

\section{e. Kriteria Safety \& Environment}

Hasil perhitungan dari alternatif pada kriteria safety \& environment ditampilkan pada Tabel 17. 
Pemilihan Provider Sand Consolidation dengan Metode Analytical Hierarchy Process

Tabel 17. Nilai weight score pada kriteria safety \& environment

\begin{tabular}{|c|c|c|c|c|c|c|}
\hline Alternatif & ST-a1-HL & ST- $\alpha 2-H L$ & SV- $\beta 1-S B$ & NG-B2-SB & SA-B2-SB & SC- $\gamma 1-B H$ \\
\hline $\begin{array}{l}\text { Kriteria Safety \& } \\
\text { Environment }\end{array}$ & 0,185 & 0,191 & 0,163 & 0,141 & 0,147 & 0,173 \\
\hline
\end{tabular}

Berdasarkan nilai bobot yang didapatkan dari hasil perhitungan pada Tabel 13, maka dapat diketahui urutan alternatif provider untuk kriteria quality mulai dari nilai tertinggi yaitu, ST- $\alpha 2-H L(0,191)$, ST- $\alpha 1-$ HL $(0,185)$, SC- $\gamma 1-B H(0,173)$, SV- $\beta 1$-SB $(0,163)$, SA- $\beta 2-S B(0,147)$, dan NG- $\beta 2-S B(0,141)$. Pada kriteria safety \& environment terlihat bahwa nilai antar alternatif tidak terlalu jauh signifikan, dari nilai ini terlihat bahwa masing-masing provider SCON memiliki standar safety \& environment yang hampir sama. Pada perusahaan minyak dan gas bumi faktor safety \& environment merupakan faktor mutlak yang harus diprioritaskan karena jenis pekerjaan pada bidang ini memiliki tingkat resiko yang tinggi (high risk).

\subsection{Perhitungan Nilai Akhir}

Untuk memilih provider terbaik dari 6 alternatif provider yang ada, maka dilakukan perhitungan dengan cara mengalikan masing-masing nilai bobot dari alternatif yang didapatkan pada Tabel 13 - Tabel 17 dengan nilai bobot dari kriteria pada Tabel 2, kemudian dijumlahkan setiap barisnya. Sehingga didapatkan nilai bobot untuk menentukan alternatif mana yang terbaik. Sebagai contoh akan menghitung weight score akhir untuk alternatif ST- $\alpha 1$-HL. Dari data Tabel 13 - Tabel 17, dilihat bahwa dengan mengalikan setiap nilai pada kolom baris ST- $\alpha 1-\mathrm{HL}$ dengan nilai bobot untuk masing-masing kriteria pada Tabel 2, maka didapat weight score akhir, yaitu:

$=(0,077 * 0,349)+(0,196 * 0,127)+(0,129 * 0,219)+(0,162 * 0,075)+(0,185 * 0,229)=0,135$.

Berikut hasil perhitungan weight score akhir untuk setiap alternatif ditampilkan pada Tabel 18.

Tabel 18. Perhitungan akhir pemilihan alternatif

\begin{tabular}{|c|c|}
\hline Kriteria & Weight Score \\
\hline ST-a1-HL & 0,135 \\
\hline ST- $\alpha 2-H L$ & 0,282 \\
\hline SV- $\beta 1-S B$ & 0,182 \\
\hline NG- $\beta 2-S B$ & 0,114 \\
\hline SA-B2-SB & 0,086 \\
\hline SC- $\gamma 1-B H$ & 0,202 \\
\hline
\end{tabular}

Berdasarkan hasil perhitungan akhir pada Tabel 18, maka provider dengan produk ST- $\alpha 2-\mathrm{HL}$ dapat direkomendasikan sebagai alternatif terbaik untuk mengatasi masalah kepasiran dengan metode sand consolidation (SCON) di PT X. Hal ini didasarkan karena mendapatkan bobot tertinggi yaitu 0,282. Kedua adalah SC- $\gamma 1-B H(0,202)$, ketiga yaitu SV- $\beta 1-S B(0,182)$, keempat yaitu ST- $\alpha 1-H L(0,135)$, kelima adalah NG- $\beta 2-S B(0,114)$, dan yang terakhir adalah SA- $\beta 2-S B(0,086)$.

\subsection{Validasi hasil perhitungan metode AHP}

Metode validasi yang digunakan adalah dengan membandingkan pendapat dari para profesional di bidangya (expert judgment) yang merupakan tim pengambil keputusan (decision maker) untuk menentukan provider SCON mana yang akan terpilih. Metode ini digunakan untuk melihat apakah metode AHP dapat mewakili keadaan sebenarnya dan apakah hasilnya juga sudah sesuai dengan keputusan tim decision maker, disamping itu dengan adanya proses validasi ini maka juga dapat membuktikan bahwa data yang digunakan adalah valid, reliabel serta bisa dipertanggungjawabkan walaupun dengan jumlah responden yang terbatas. Untuk mengetahui validasi hasil dari analisis dengan metode AHP maka akan dilakukan perbandingan hasil perangkingan alternatif provider oleh para decision maker terhadap hasil perangkingan dengan metode AHP. Hasilnya disajikan pada Tabel 19.

Tabel 19. Rekapitulasi perbandingan hasil menurut expert judgment dan AHP

\begin{tabular}{|c|c|c|c|c|c|}
\hline & Decision maker 1 & Decision maker 2 & Decision maker 3 & Decision maker 4 & $\begin{array}{c}\text { Metode } \\
\text { AHP }\end{array}$ \\
\hline ST-a1-HL & 3 & 2 & 5 & 4 & 4 \\
\hline ST- $\alpha 2-H L$ & 1 & 1 & 1 & 1 & 1 \\
\hline SV-ק1-SB & 4 & 3 & 3 & 3 & 3 \\
\hline
\end{tabular}


Rony Arjuna, Joko Waluyo, Nur Aini Masruroh

\begin{tabular}{|c|c|c|c|c|c|}
\hline NG-B2-SB & 5 & 5 & 2 & 5 & 5 \\
\hline SA- $\beta 2-S B$ & 6 & 6 & 6 & 6 & 6 \\
\hline \multirow[t]{2}{*}{ SC- $\gamma 1-B H$} & 2 & 4 & 4 & 2 & 2 \\
\hline & \multicolumn{4}{|c|}{ Decision maker 1} & $66,67 \%$ \\
\hline \multirow{4}{*}{$\begin{array}{l}\text { Persentase } \\
\text { ketepatan } \\
\text { hasil }\end{array}$} & \multicolumn{4}{|c|}{ Decision maker 2} & $66,67 \%$ \\
\hline & \multicolumn{4}{|c|}{ Decision maker 3} & $50 \%$ \\
\hline & \multicolumn{4}{|c|}{ Decision maker 4} & $100 \%$ \\
\hline & \multicolumn{4}{|c|}{ Rata-rata } & $70,84 \%$ \\
\hline
\end{tabular}

Secara umum hasil perhitungan rata-rata ketepatan hasil pemilihan provider dari tim decision maker dibandingkan dengan hasil dari metode AHP menunjukkan angka di atas 70,84\%. Memang terjadi perbedaan dalam perangkingan, akan tetapi tidak terlalu signifikan. Dapat dilihat untuk alternatif ST- $\alpha 2-\mathrm{HL}$ selalu berada pada urutan 1 dari perangkingan oleh setiap decision maker, artinya pada dasarnya seluruh decision maker menyetujui bahwasanya ST- $\alpha 2-\mathrm{HL}$ merupakan salah satu alternatif terbaik. Apabila dicermati lagi, dalam kasus ini provider yang akan terpilih hanya ada 1 saja (urutan 1), ini berarti urutan ke 2 sampai dengan ke 6 bisa diabaikan. Apabila didetailkan lagi maka ketepatan atau validasi dapat diukur hanya dari pilihan best alternatifnya saja. Maka ketepatan hasil perbandingannya jika hanya menggunakan parameter best alternatif saja adalah $100 \%$, karena dari 4 decision maker semuanya yang memilih ST- $\alpha 2-H L$ pada urutan pertama.

Hasil penelitian menunjukkan bahwa penggunaan metode AHP memiliki akurasi yang cukup tinggi untuk diterapkan pada kasus pemilihan provider SCON. Di samping itu keunggulan penggunaan metode AHP dalam kasus ini adalah terbentuknya sistem pemilihan provider SCON yang lebih objektif karena dapat meminimalisir terjadinya pemilihan berdasarkan subjektifitas para decision maker.

\section{Kesimpulan}

Berdasarkan hasil pengembangan sistem dengan Analytic Hierarchy Process (AHP), maka kriteria yang dapat dijadikan sebagai bahan pertimbangan dalam memilih provider terbaik dalam mengatasi masalah kepasiran adalah compatibility (0,349), safety \& environment $(0,229)$, quality $(0,219)$, cost $(0,127)$, dan terakhir adalah service $(0,075)$. Kemudian dari hasil analisis yang telah dilakukan terhadap 6 alternatif yang ada, maka provider terbaik yang dipilih untuk mengatasi masalah kepasiran dengan metode sand consolidation (SCON) adalah ST- $\alpha 2-\mathrm{HL}$ dengan nilai bobot 0,282. Pengembangan sistem pengambilan keputusan dengan AHP dapat diterapkan sebagai metode yang sangat baik dalam kasus penentuan best alternatif provider SCON. Perbandingan hasil pilihan best alternatif antara decision maker dan metode AHP jika dilihat dari perspektif best alternatif saja maka angka perbandingannya mencapai $100 \%$. Terlihat bahwa dengan penggunaan metode AHP maka proses pemilihan akan menjadi lebih objektif karena hasil pilihannya didasarkan pada evaluasi nilai dengan bobot kriteria yang standar, sehingga pemilihan provider SCON lebih transparan dan terukur. Keputusan akhirnya pun menjadi bisa dipertanggungjawabkan dan juga diharapkan tidak terjadi lagi penentuan provider yang didasarkan pada subjektifitas decision maker.

\section{DAFTAR PUSTAKA}

[1] O. F. Maduabuchi, D. Appah, dan E. S. Okoro, "Relative Study of Internal Gravel Packing and Chemical Sand Consolidation: Sand Control Techniques of Niger Delta Wells," Am. J. Eng. Res., vol. 6, no. 5, pp. 261-268, 2017.

[2] K. A. Zahroh, "Evaluasi Problem Kepasiran Pada Sumur - Sumur di Lapangan X,” Universitas Trisakti, 2016.

[3] O. Charles, U. Stephen, dan E. Onyekazi, "Comparative Study of The Sand Control Methods Used in the Oil Industry (Case Study of The Niger Delta)," Interational J. Sci. Eng. Res., vol. 7, no. 8, pp. 1497-1506, 2016.

[4] H. Taherdoost, "Decision Making Using the Analytic Hierarchy Process (AHP); A Step by Step Approach," Int. J. Econ. Manag. Syst., vol. 2, pp. 244-246, 2017.

[5] A. Supriadi, A., dan Rustandi, Analytical Hierarchy Process (AHP) Teknik Penentuan Strategi Daya Saing Kerajinan Bordir. Tasikmalaya: Deepublish, 2016.

[6] B. Luzon, dan S. El Sayegh, "Evaluating supplier selection criteria for oil and gas projects in the UAE using AHP and Delphi," International Journal of Construction Management, vol. 16, pp. 175 - 183, 2016.

[7] C.N Wang, H.T Tsai, T.P. Ho, V.T. Nguyen, dan Y.F. Huang, "Multi-Criteria Decision Making (MCDM) Model for Supplier Evaluation and Selection for Oil Production Projects in Vietnam" Processes, vol. 8, no. 134, pp.1-13, 2020.

[8] C. Jack Kie, A. Khalif Hassan, N. Mohd Aripin, and R. Mohd Yunus, "An Analytic Hierarchy Process Approach in Decision-Making for Material Selection in an Automotive Company: A Case Study," KnE Soc. Sci., vol. 2019, pp. 472-484, 2019.

[9] P. Z. Razi, N. I. Ramli, M. I. Ali, dan P. J. Ramadhansyah, "Selection of Contractor by Using Analytical Hierarchy Process (AHP),” IOP Conf. Ser. Mater. Sci. Eng., vol. 712, no. 1, 2020. 
Pemilihan Provider Sand Consolidation dengan Metode Analytical Hierarchy Process

[10] R. S. Ilhami and D. Rimantho, "Penilaian Kinerja Karyawan dengan Metode AHP dan Rating Scale," J. Optimasi Sist. Ind., vol. 16, no. 2, pp. 150-157, 2017.

[11] A. Siekelova, I. Podhorska, dan J.J. Imppola, "Analytic Hierarchy Process in Multiple Criteria Decision Making: A Model Example," SHS Web of Conf., vol. 90, no. 01019, pp. 1-10, 2021. 